\title{
ANALISIS KESESUAIAN MATERI IPA DALAM BUKU SISWA KELAS IV SEMESTER 1 SD/MI DENGAN KURIKULUM 2013
}

\author{
Teguh Yunianto ${ }^{1}$, Mohamad Agung Rokhimawan ${ }^{2}$ \\ ${ }^{1,2}$ Universitas Islam Negeri Sunan Kalijaga Yogyakarta
}

\begin{abstract}
In the 2013 curriculum, learning materials in SD/MI were packaged in integrated thematic learning models, although the learning materials and processes were carried out in an integrated thematic manner, but the material taught could not be separated from the material concepts of each content. The material has been contained in student books, while the learning process is contained in the teacher's book. Books have an important role in carrying out learning, namely as a medium of liaison between students, teachers, and the most common curriculum. Textbooks are one of the supporting factors in determining learning success. Along with curriculum changes, textbooks also experience changes as needed to support students' understanding in learning. This study aims to analyze the suitability of science material in class IV semester 1 textbooks with the 2013 curriculum. The method used in this study is qualitative. The aim is to analyze a textbook, which is done by describing the goals that have been determined. This type of research is documentary analysis or content analysis. The results of the analysis stated that the science material in class IV textbooks SD / MI in accordance with the 2013 curriculum.
\end{abstract}

Keyword: Science Material, Class IV SD / MI, Analysis

\begin{abstract}
Abstrak: Pada kurikulum 2013, materi pembelajaran di SD/MI dikemas dalam model pembelajaran tematik terpadu, meskipun materi dan proses pembelajaran dilakukan secara tematik terpadu, namun materi yang diajarkan tidak boleh terlepas dari konsep materi dari masing-masing muatan. Adapun materi tersebut telah tertuang dalam buku siswa, sedangkan proses pembelajaran terdapat pada buku guru. Buku memiliki peran yang penting dalam melaksanakan pembelajaran, yaitu sebagai media penghubung antar siswa, guru, dan kurikulum yang paling umum. Buku ajar merupakan salah satu faktor pendukung dalam menentukan keberhasilan pembelajaran. Seiring dengan perubahan kurikulum, buku ajar pun mengalami perubahan sesuai kebutuhan guna menunjang pemahaman peserta didik dalam belajar. Penelitian ini bertujuan untuk menganalisis kesesuain materi IPA dalam buku ajar kelas IV semester 1 dengan kurikulum 2013. Metode yang digunakan dalam penelitian ini adalah kualitatif. Tujuannya adalah untuk menganalisis suatu buku teks, yang mana hal ini dilakukan dengan cara mendiskripsikan tujuan yang telah ditentukan. Jenis penelitian ini adalah penelitian dokumen (documentary analysis) atau analisis isi (content analysis). Hasil analisis menyatakan bahwa materi IPA dalam buku siswa kelas IV SD/MI sesuai dengan kurikulum 2013.
\end{abstract}

Kata Kunci: Materi IPA, Kelas IV SD/MI, Analisis

'Universitas Islam Negeri Sunan Kalijaga Yogyakarta, Email: teguhyunianta96国gmail.com

${ }^{2}$ Universitas Islam Negeri Sunan Kalijaga Yogyakarta, Email: rokhimawan7g国gmail.com 


\section{PENDAHULUAN}

Sumber belajar dapat diartikan sebagai segala sesuatu yang dapat dimanfaatkan untuk membantu tercapainya tujuan pembelajaran. Sumber belajar dibedakan menjadi dua macam, yaitu (1) sumber belajar yang dimanfaatkan (2) sumber belajar yang dirancang. Sumber belajar yang dimanfatkan adalah segala sesuatu yang ada disekitar kita yang dapat dimanfaatkan untuk keperluan belajar, contohnya seperti surat kabar, siaran televisi, kebun binatang, museum dan masjid. Seadangkan sumber belajar yang dirancang adalah sumber belajar yang secara sengaja diranvang dan dibuat untuk mencapai tujuan pembelajaran tertentu, contohnya seperti buku paket, LKS, modul dan media (Prastowo, 2014, hlm.126).

Bahan ajar adalah seperangkat materi berupa fakta, konsep, prinsip, prosedur, atau generalisasi yang disusun secara sistematis baik tertulis maupun tidak tertulis yang digunakan untuk membantu pendidik dalam pembelajaran dan memungkinkan peserta didik untuk belajar dalam rangka mencapai tujuan yang diharapkan (Fairuz, 2018). Salah satu bahan ajar yang umum digunakan adalah bahan ajar visual (cetak) berupa buku. Menurut Majid (2007), buku adalah sejumlah lembaran kertas, baik memuat konten maupun kosong, yang dijilid dan diberi kulit. Buku sebagai bahan ajar merupakan buku yang berisi suatu ilmu pengetahuan hasil analisis terhadap kurikulum dalam bentuk tertulis. Buku terdiri dari beberapa bab. Tiap bab dapat berisi beberapa subbab atau subbagian dan seterusnya sesuai dengan cakupan dan ruang lingkup pembahasan bahan pembelajaran pada pokok bahasan bersangkutan. Peraturan Menteri Pendidikan Nomor 8 Tahun 2016 menyebutkan bahwa buku teks pelajaran adalah sumber pembelajaran utama untuk mencapai kompetensi dasar dan kompetensi inti yang dinyatakan layak oleh Kementerian Pendidikan dan Kebudayaan untuk digunakan satuan pendidikan.
Penilaian kelayakan diajukan kepada Badan Standar Nasional Pendidikan (BSNP).

Buku ajar harus relevan dengan kurikulum yang berlaku. Kurikulum yang sedang berlaku adalah kurikulum 2013 yang merupakan tindak lanjut dari kurikulum berbasis kompetensi dan pengembangan dari kurikulum tingkat satuan pendidikan. Kurikulum 2013 mencakup tiga kompetensi capaian, yaitu kompetensi pengetahuan, sikap, dan keterampilan secara terpadu. Mulyasa (2013) mengungkapkan bahwa salah satu perubahan dalam kurikulum 2013 adalah standar isi di mana di dalamnya ada perubahan terkait penguatan materi melalui evaluasi. Hasil evaluasi tersebut adalah (1) menghilangkan materi yang tidak esensial dan tidak relevan; (2) memuat materi yang relevan dengan kebutuhan peserta didik; (3) menambah materi yang dianggap penting; (4) meninjau kembali kedalaman materi sesuai dengan tuntutan era. Hasil evaluasi ini menyebabkan adanya penyusunan kembali kompetensi dasar yang sesuai dengan materi yang dibutuhkan. Selama 6 tahun kurikulum 2013 sering mengalami revisi. Hal ini berakibat pada buku ajar. Buku ajar yang dikembangkan oleh pusat kurikulum dan perbukuan kementerian pendidikan dan kebudayaan (puskurbuk kemdikbud) mengalami revisi atau perubahan di hampir setiap tahun, mulai dari tahun 2014, 2016, dan yang terakhir tahun 2017. Revisi ini merupakan salah satu indikasi bahwa dalam penyusunannya masih banyak kekurangan.

Peraturan Menteri Pendidikan dan Kebudayaan Nomor 21 Tahun 2016 tentang standar isi pendidikan dasar dan menengah terdiri dari tingkat kompetensi dan kompetensi inti sesuai dengan jenjang dan jenis pendidikan. Kompetensi inti meliputi sikap spiritual, sikap sosial, pengetahuan, dan keterampilan. Ruang lingkup materi yang spesifik dirumuskan berdasarkan tingkat kompetensi dan kompetensi inti untuk mencapai kompetensi lulusan. Kurikulum 2013 pada jenjang SD/MI 
menggunakan pembelajaran tematik dari kelas I sampai kelas VI. Pembelajaran tematik merupakan salah satu pembelajaran terpadu tipe webbed dimana berbagai disiplin ilmu dipadukan dalam satu tema tertentu (Fogarty, 1991). Pembelajaran tematik memberikan pengalaman belajar satu tema dari berbagai sudut pandang ilmu pengetahuan. Dengan demikian, beberapa kompetensi dapat tercapai sekaligus.

Buku ajar tematik kurikulum 2013 terdiri dari buku guru dan buku siswa. Sebuah tema dimuat dalam satu buku dan setiap tema memiliki beberapa subtema. Peneliti membahas materi IPA yang ada dalam buku tematik kelas IV. Buku tematik kelas IV memiliki sembilan tema dan setiap tema terdiri dari tiga subtema. Setiap tema memuat materi pembelajaran dari berbagai disiplin ilmu. Materi pembelajaran adalah pengetahuan, keterampilan, dan sikap yang harus dikuasai oleh peserta didik dalam angrangka memenuhi standar isi yang telah ditetapkan. Materi pembelajaran umumnya merupakan gabungan antara jenis materi yang berbentuk pengalaman (fakta dan informasi yang terperinci), keterampilan (langkah-langkah, prosedur, keadaan, dan syarat-syarat tertentu), dan sikap (berisi pendapat, ide, saran, atau tanggapan). Kurikulum 2013 secara bertahap diimpelementasikan di berbagai sekolah pada setiap jenjang pendidikan. Buku ajar yang dikembangkan kementerian pendidikan dan kebudayaan didistribusikan secara bertahap pula. Namun, distribusi buku dan implementasi kurikulum di setiap jenjang pendidikan terkesan terburu-buru dan menimbulkan pertanyaan akibat banyaknya revisi yang dilakukan. Dengan demikian, penelitian ini dilakukan untuk menjawab pertanyaan terkait bagaimana kesesuaian isi materi IPA dalam buku ajar tematik SD/MI dengan kurikulum yang sedang berlaku sehingga diharapkan buku ajar yang digunakan sesuai dengan kompetensi yang ingin dicapai (Fairuz, 2019, hlm. 79).
Dengan adanya perubahan kurikulum 2013 tersebut, maka buku yang dipakai sebagai buku pegangan guru dan siswa juga disesuaikan dengan perkembangan kurikulum yang terbaru. Saat ini pemerintah telah menerbitkan buku pegangan bagi guru dan siswa. Buku yang telah diterbitkan oleh Kementerian Pendidikan dan Kebudayaan Republik Indonesia berbeda dengan buku-buku yang telah ada. Buku ajar ini bentuknya bukan lagi mata pelajaran melainkan tema, sesuai dengan kurikulum 2013 yang sifatnya tematik integratif. Buku-buku yang telah diterbitkan oleh Kementerian Pendidikan dan Kebudayaan Republik Indonesia 2013 perlu dikaji (Estiningtyas, 2015, hlm. 186).

Dalam artikel ini membahas tentang analisis tema 1 indahnya kebersamaan (sub tema 1 keberagaman budaya bangsaku, sub tema 2 kebersamaan dalam keluarga sub tema 3 bersyukur atas keberagaman), tema 2 selalu berhemat energi (sub tema 1 sumber energi, sub tema 2 manfaat energi sub tema 3 energi alternatif), tema 3 peduli terhadap makhluk hidup (sub tema 1 hewan dan tumbuhan dilingkungan rumahku, sub tema 2 keberagaman mahkluk hidup dilingkunganku, sub tema 3 ayo cintai lingkungan), tema 4 berbagi pekerjaan (sub tema 1 jenis-jenis pekerjaan, sub tema 2 pekerjaan disekitarku, sub tema 3 pekerjaan orang tuaku), dan tema 5 pahlawanku (sub tema 1 perjuangan para pahlawanku, sub tema 2 pahlawan kebangganku, sub tema 3 sikap kepahlawanan).

\section{METODOLOGI PENELITIAN}

Penelitian ini menggunakan pendekatan kualitatif dengan metode yang digunakan dalam penelitian ini adalah deskriptif (Gusviani, 2016, hlm. 98). Tujuannya adalah untuk menganalisis suatu buku teks, yang mana hal ini dilakukan dengan cara mendiskripsikan tujuan yang telah ditentukan. Jenis penelitian ini adalah penelitian dokumen (documentary analysis) atau analisis isi (content analysis) (Nova dan Habudin, 2017, hlm. 116). Analisis datanya adalah isi materi ipa buku 
guru dan buku siswa kelas IV semester 1

SD/MI kurikulum 2013.

\section{HASIL PENELITIAN DAN \\ PEMBAHASAN}

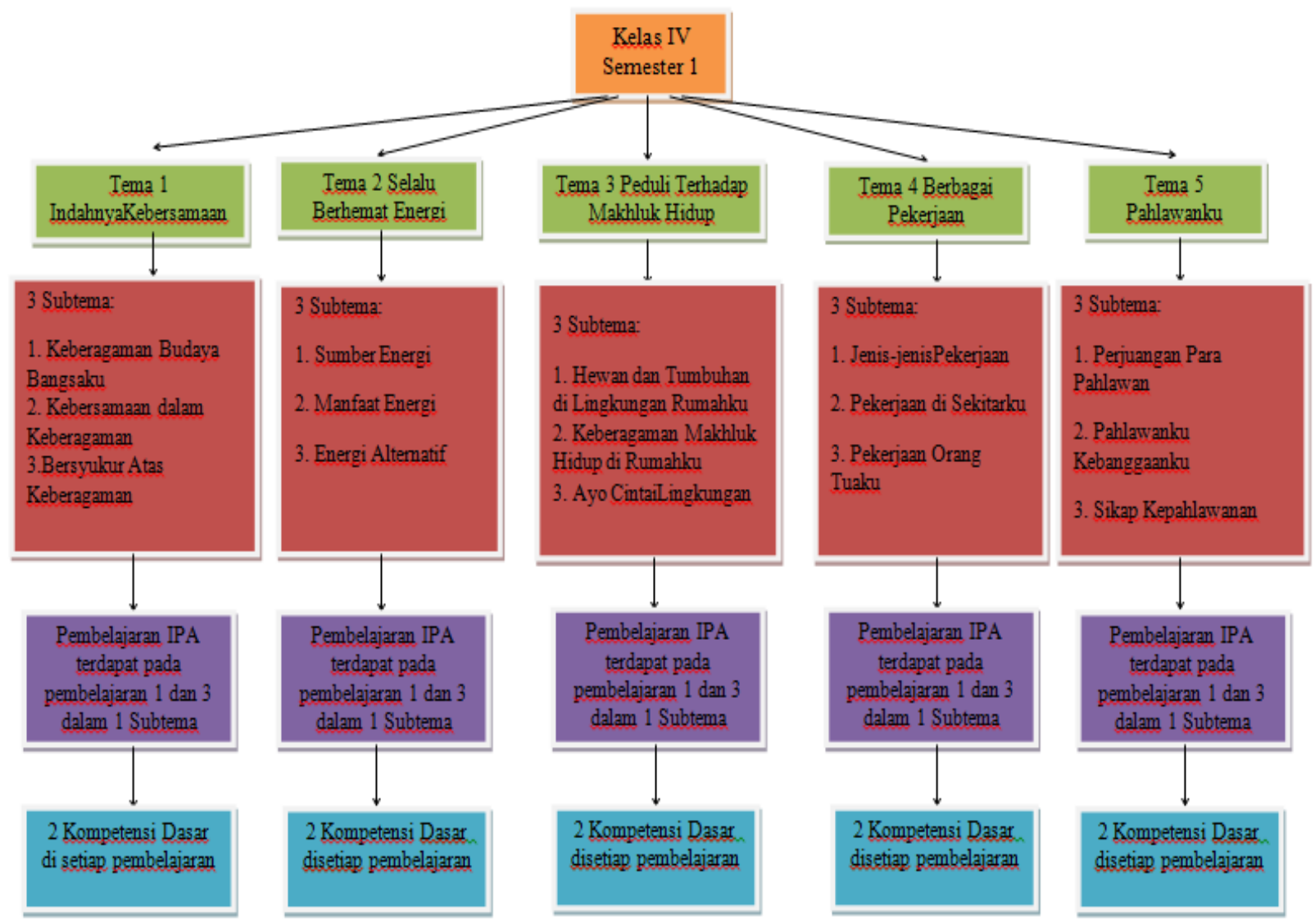

Gambar 1: Analisis Flowchat Pemetaan Kompetensi dasar

Materi ajar IPA mengacu pada kompetensi dasar sesuai amanat kurikulum 2013. Didalamnya dirumuskan secara terpadu kompetensi sikap, pengetahuan dan keterampilan yang harus dikuasi peserta didik. Kemudian dirumuskan juga proses pembelajaran dan penilaian untuk memastikan ketercapaian kompetensi yang diinginkan. Proses pembelajaran dirancang berbasis aktivitas dengan melibatkan peserta didik secara aktif dalam proses pembelajaran. Pada kurikulum 2013 kelas IV semster 1 terdapat 5 tema setiap tema terdiri dari 3 subtema dan setiap subtema terdiri 6 pembelajaran dan 2 kompetensi dasar, materi ilmu pengetahuan alam terdapat di pembelajaran 1 dan pembelajaran 3 di setiap subtemanya.

Tema 1 pada buku ajar tematik kelas IV SD/MI adalah indahnya kebersamaan KD 3.6 Menerapkan sifatsifat bunyi dan keterkaitannya dengan indera pendengaran dan KD 4.6 Menyajikan laporan hasil percobaan tentang sifat-sifat bunyi. Materi pada KD ini dibagi pada tiga subtema, yaitu (1) keberagaman budaya bangsaku, (2) kebersamaan dalam keluarga, (3) bersyukur atas keberagaman.

Tema 2 pada buku ajar tematik kelas IV SD/MI adalah selalu berhemat energi KD 3.5 Mengidentifikasi berbagai 
sumber energi, perubahan bentuk energi, dan sumber energi alternatif (angin, air, matahari, panas bumi, bahan bakar organik, dan nuklir) dalam kehidupan sehari-hari dan KD 4.5 Menyajikan laporan hasil pengamatan dan penelusuran informasi tentang berbagai perubahan bentuk energi. Materi pada KD ini dibagi pada tiga subtema, yaitu (1) sumber energi, (2) manfaat energi, (3) energi alternatif.

Tema 3 pada buku ajar tematik kelas IV SD/MI adalah peduli terhadap makhluk hidup KD 3.8 Menjelaskan pentingnya upaya keseimbangan dan pelestarian sumber daya alam di lingkungannya dan KD 4.8 Melakukan kegiatan upaya pelestarian sumber daya alam bersama orang-orang di lingkungannya. Materi pada KD ini dibagi pada tiga subtema, yaitu (1) hewan dan tumbuhan dilingkungan rumahku, (2) keberagaman mahluk hidup dilingkunganku, (3) ayo cintai lingkungan.

Tema 4 pada buku ajar tematik kelas IV SD/MI adalah berbagi pekerjaan KD 3.8 Menjelaskan pentingnya upaya keseimbangan dan pelestarian sumber daya alam di lingkungannya dan KD 4.8 Melakukan kegiatan upaya pelestarian sumber daya alam bersama orang-orang di lingkungannya. Materi pada KD ini dibagi pada tiga subtema, yaitu (1) jenis-jenis pekerjaan, (2) pekerjaan disekitarku (3) pekerjaan orang tuaku.

Tema 5 pada buku ajar tematik kelas IV SD/MI adalah pahlawanku KD 3.7 Menerapkan sifat-sifat cahaya dan keterkaitannya dengan indera penglihatan dan KD 4.7 Menyajikan laporan hasil percobaan tentang sifat-sifat cahaya. Materi pada KD ini dibagi pada tiga subtema, yaitu (1) perjuangan para pahlawanku, (2) pahlawan kebanggaanku, (3) sikap kepahlawanan.

Dari pemetaan kompetensi dasar di atas maka pembahasan dari penelitian ini adalah sebagai berikut:
Tema 1 Indahnya Kebersamaan

Sub tema 1 keberagaman budaya bangsaku, indikatornya menghasilkan bunyi dari beragam benda di sekitar dengan lengkap dan menyajikan laporan hasil pengamatan tentang cara menghasilkan bunyi dari beragam benda di sekitar dengan sistematis, materi cara menghasilkan bunyi, materi ipa pembelajaran 1 dibuku guru terdapat dihalaman 10 sedangkan dibuku siswa halaman 10 dan pembelajaran 3 buku guru materi ipa terdapat di halam 34 serta dibuku siswa dihalaman 36 , materi subtema 1 termasuk dalam C3 (lots).

Sub tema 2 kebersamaan dalam keluarga, indikatornya Mengidentifikasi sumber bunyi dan Menyajikan laporan percobaan tentang sumber bunyi., materi sumber bunyi, materi ipa pembelajaran 1 dibuku guru terdapat dihalaman 84 sedangkan dibuku siswa halaman 80 dan pembelajaran 3 buku guru materi ipa terdapat di halam 108 serta dibuku siswa dihalaman 103, materi subtema 2 termasuk dalam C4 (hots) dan C3 (lots).

Sub tema 3 bersyukur atas keberagaman, indikatornya mengidentifikasi sifat-sifat bunyi memantul dan menyerap dengan lengkap dan menyajikan laporan sifat-sifat bunyi memantul dan menyerap dengan sistematis, materi sifat-sifat bunyi memantul dan menyerap, materi ipa pembelajaran 1 dibuku guru terdapat dihalaman 152 sedangkan dibuku siswa halaman 135 dan pembelajaran 3 buku guru materi ipa terdapat di halam 172 serta dibuku siswa dihalaman 152, materi subtema 2 termasuk dalam C4 (hots) dan C3 (lots).

Tema 2 Selalu Berhemat Energi

Sub tema 1 Sumber Energi, indikatornya Menjelaskan manfaat energi matahari dalam kehidupan sehari-hari dan Menyajikan laporan hasil pengamatan tentang perubahan bentuk energi matahari, materi Manfaat energi matahari dan Perubahan bentuk energi, materi ipa pembelajaran 1 dibuku guru terdapat dihalaman 6 sedangkan dibuku siswa 
halaman 3 dan pembelajaran 3 buku guru materi ipa terdapat di halam 30 serta dibuku siswa dihalaman 23, materi subtema 1 termasuk dalam C3 (lots).

Sub tema 2 Manfaat Energi, indikatornya Mengidentifikasi manfaat perubahan bentuk energi dalam kehidupan sehari-hari dan Menyajikan laporan hasil pengamatan tentang berbagai perubahan bentuk energi dalam kehidupan seharihari., materi manfaat perubahan bentuk energi, materi ipa pembelajaran 1 dibuku guru terdapat dihalaman 59 sedangkan dibuku siswa halaman 53 dan pembelajaran 3 buku guru materi ipa terdapat di halam 74 serta dibuku siswa dihalaman 69, materi subtema 2 termasuk dalam C4 (hots) dan C3 (lots).

Sub tema 3 energi alternatif, indikatornya Mengidentifikasi manfaat tentang sebagai sumber energi alternatif dalam kehidupan sehari-hari dan Menyajikan laporan hasil pengamatan tentang perubahan bentuk energi, materi manfaat energi alternatif, materi ipa pembelajaran 1 dibuku guru terdapat dihalaman 107 sedangkan dibuku siswa halaman 100 dan pembelajaran 3 buku guru materi ipa terdapat di halam 121 serta dibuku siswa dihalaman 115 , materi subtema 3 termasuk dalam C4 (hots) dan C3 (lots).

\section{Tema 3 Peduli Terhadap Makhluk Hidup}

Sub tema 1 hewan dan tumbuhan disekitar rumahku, indikatornya Mengidentifikasi masalah-masalah keseimbangan lingkungan dan Melakukan identifikasi masalah keseimbangan lingkungan, materi tumbuhan dan fungsinya, materi ipa pembelajaran 1 dibuku guru terdapat dihalaman 6 sedangkan dibuku siswa halaman 3 dan pembelajaran 3 buku guru materi ipa terdapat di halam 27 serta dibuku siswa dihalaman 20, materi subtema 1 termasuk dalam C4 (hots) dan C6 (hots).

Sub tema 2 keberagaman makhluk hidup dilingkunganku, indikatornya Mengidentifikasi fungsi hewan dalam pelestarian lingkungan dan menjelaskan pentingnya peran hewan sebagai sumber daya alam dalam menjaga keseimbangan alam, materi Pentingnya peran hewan sebagai sumber daya alam dalam menjaga keseimbangan alam, materi ipa pembelajaran 1 dibuku guru terdapat dihalaman 71 sedangkan dibuku siswa halaman 50 dan pembelajaran 3 buku guru materi ipa terdapat di halam 92 serta dibuku siswa dihalaman 66, materi subtema 2 termasuk dalam C4 (hots) dan C3 (lots).

Sub tema 3 ayo cintai lingkungan, indikatornya Menjelaskan penting penghijauan sebagai salah satu upaya pelestarian sumber daya alam dan Melakukan kegiatan menanam tanaman sebagai upaya pelestarian sumber daya alam dan lingkungan, materi upaya pelestarian sumber daya alam, materi ipa pembelajaran 1 dibuku guru terdapat dihalaman 132 sedangkan dibuku siswa halaman 98 dan pembelajaran 3 buku guru materi ipa terdapat di halam 152 serta dibuku siswa dihalaman 112, materi subtema 3 termasuk dalam C3 (lots) dan C6 (hots).

\section{Tema 4 Berbagi Pekerjaan}

Sub tema 1 Jenis-jenis Pekerjaan, indikatornya Mengidentifikasi pentingnya keseimbangan alam dan kelestarian sumber daya alam dan Memberikan contoh kegiatan menjaga kelestarian sumber daya alam, materi Cara menjaga keseimbangan alam dan kelestarian sumber daya alam, materi ipa pembelajaran 1 dibuku guru terdapat dihalaman 7 sedangkan dibuku siswa halaman 6 dan pembelajaran 3 buku guru materi ipa terdapat di halam 30 serta dibuku siswa dihalaman 26, materi subtema 1 termasuk dalam C4 (hots) dan C3 (lots).

Sub tema 2 Pekerjaan disekitarku, indikatornya Mengidentifikasin dampak pemanfaatan teknologi bagi keseimbangan alam dan kelestarian sumber daya alam. Dan Mengembangkan contoh pemanfaatan teknologi yang ramah lingkungan bagi kelestarian sumber daya alam, materi Dampak penggunaan teknologi bagi 
keberadaan sumber daya alam, materi ipa pembelajaran 1 dibuku guru terdapat dihalaman 81 sedangkan dibuku siswa halaman 53 dan pembelajaran 3 buku guru materi ipa terdapat di halam 104 serta dibuku siswa dihalaman 73 , materi subtema 2 termasuk dalam C4 (hots) dan C6 (hots).

Sub tema 3 Pekerjaan Orang Tuaku, Mengidentifikasi pentingnya pemanfaatan barang bekas sebagai usaha pelestarian sumber daya alam dan Mengomunikasikan contoh kegiatan pemanfaatan sampah sebagai upaya pelestarian sumber daya alam, materi sampah sebagai upaya menjaga kelestarian alam dalam kehidupan sehari-hari, materi ipa pembelajaran 1 dibuku guru terdapat dihalaman 139 sedangkan dibuku siswa halaman 99 dan pembelajaran 3 buku guru materi ipa terdapat di halam 158 serta dibuku siswa dihalaman 114, materi subtema 3 termasuk dalam C4 (hots) dan C3 (lots).

\section{Tema 5 Pahlawanku}

Sub tema 1 Perjuangan Para Pahlawanku, indikatornya Mengidentifikasi sifat-sifat cahaya dan keterkaitannya dengan indera penglihatan dalam kehidupan sehari- hari. Dan Melaporkan hasil percobaan yang memanfaatkan sifat- sifat cahaya dalam bentuk tulisan, materi Sifat-sifat cahaya dan hubungannya dengan penglihatan, materi ipa pembelajaran 1 dibuku guru terdapat dihalaman 11 sedangkan dibuku siswa halaman 7 dan pembelajaran 3 buku guru materi ipa terdapat di halam 34 serta dibuku siswa dihalaman 26, materi subtema 1 termasuk dalam $\mathrm{C} 4$ (hots).

$\underset{\text { Kebanggaanku, }}{\text { Sub tema } 2} \begin{array}{r}\text { Pahlawan } \\ \text { indikatornya }\end{array}$

Mengidentifikasi sifat-sifat cahaya dan keterkaitannya dengan indera penglihatan dalam kehidupan sehari- hari dan Melaporkan hasil percobaan cahaya dan cermin yang memanfaatkan sifat-sifat cahaya dalam bentuk tulisan, materi Menulis laporan tentang sifat cahaya dan hubungannya dengan penglihatan, materi ipa pembelajaran 1 dibuku guru terdapat dihalaman 75 sedangkan dibuku siswa halaman 57 dan pembelajaran 3 buku guru materi ipa terdapat di halam 93 serta dibuku siswa dihalaman 72, materi subtema 2 termasuk dalam $\mathrm{C} 4$ (hots).

Sub tema 3 Sikap Kepahlawanan, indikatornya Mengidentifikasi sifat- sifat cahaya melalui percobaan dengan periskop yang dibuat sendiri dan Melaporkan hasil percobaan sifat cahaya melalui percobaan dengan periskop yang dibuat sendiri, materi periskop, materi ipa pembelajaran 1 dibuku guru terdapat dihalaman 128 sedangkan dibuku siswa halaman 94 dan pembelajaran 3 buku guru materi ipa terdapat di halam 146 serta dibuku siswa dihalaman 114, materi subtema 3 termasuk dalam $\mathrm{C} 4$ (hots).

$\begin{array}{clr}\text { Berdasarkan artikel } & \text { dari } & \text { anding }\end{array}$ Kesesuaian Buku Ajar Tema Indahnya Kebersamaan Kelas IV SD Dengan Kurikulum 2013, artikel tersebut memiliki tujuan untuk mengetahui kesesuaia buku ajar kelas IV SD tema indahnya kebersamaan dengan kurikulum 2013, dalam artikel ini berpendapat masih ada bebrapa mata pelajaran yang belum sesuai dengan kurikulum 2013 selain itu materi yang disajikan dalam buku ini belum dijelaskan secara mendalam. peneliti sependapat dengan pendapat Estiningtyas (2015) bawasanya didalam tema 1 indanya kebersamaan masih ada kekurang di dalam materi, adapun temuan peneliti dalam tema 1 indahnya kebersamaan masih ada beberapa materi IPA yang masih termasuk kategori C3 (LOST).

Serta menurut artikel Karli dengan judul Penerapan Pembelajaran Tematik SD di Indonesia, adapun hasil dari penelitianya Pembelajaran tematik dapat dilaksanakan di sekolah dasar terutama di kelas 1-3 (Karli, 2010, hlm. 10). Namun peneliti tidak sependapat dengan penelitian Karli karena untuk saat ini pembelajaran tematik dilakukan di semua kelas baik kelas tinggi (4-6) maupun kelas rendah (1-3) dengan menggunakan kurikulum 2013. 
Sedangkan artikel Indahsari dengan judul Analisis Kesesuaian Buku Siswa Kelas IV SD Berbasis Kurikulum 2013 Tema Pahlawanku Subtema Perjuangan Para Pahlawanku, adapun tujuan dari artikel Bernadine Ajeng Indahsari untuk mengetahui kesesuaian buku siswa kelas IV berbasis kurikulum 2013 pada tema pahlawanku dengan KD, indikator, kegiatan, materi, alat dan sumber belajar, artikel ini berpendapat masih banyak ditemukan ketidaksesuain, kurang sesuainya KD yang dipetakan, indikator yang belum mencakup $\mathrm{KD}$, tujuan dan indikator yang kurang terkait serta materi pembelajaran yang terlalu sempit (Indahsari, 2018, hlm. 37). Peneliti tidak satu pendapat dengan artikel Bernadine Ajeng Indahsari adapun temuan atau menurut peneliti indikatror sudah mencakup KD, materi yang diajarkan sudah sesuai dengan kurikulum 2013 dan materi IPA pada subtema perjuangan para pahlawanku sudah termasuk dalam kategori C4 (HOTS).

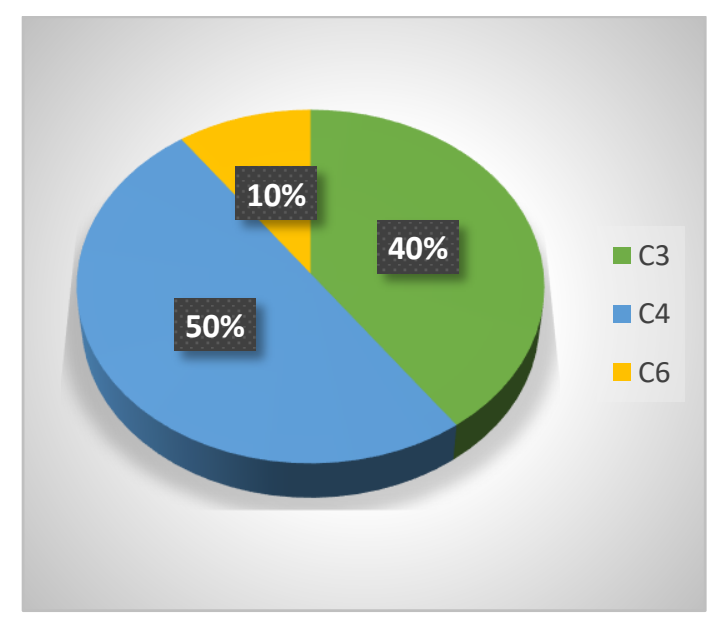

Diagram 1: lots dan host

Berdasarkan diagram diatas dapat dilihat materi IPA kelas 4 semester 1 tema 1 samapi tema 5 yang termasuk kategori C3 (LOST) 40\%, C4 (HOST) $50 \%$ dan kategori C6 (HOST) $10 \%$.

\section{KESIMPULAN}

analisis dan pembahasan yang telah dilakukan, dapat disimpulkan bahawa materi IPA pada buku guru dan buku siswa kelas IV semester $1 \mathrm{SD} / \mathrm{MI}$ edisi revisi 2017 sesuai dengan kurikulum 2013, dari tema 1 sampai tema 5 pada materi IPA kelas IV semester I yang termasuk kategori C3 (LOST) 40\%, C4 (HOST) 50\% dan kategori C6 (HOST) $10 \%$.

Berdasarkan temuan dari penelitian ditemukan di tema 1 indahnya kebersamaan ada beberapa materi yang kurang mendalam dan di tema 1 ada sebagian subtema yang materinya masih masih dalam kategori C3 (LOST). peneliti menyarankan atau mengarapkan adanya perbaikan pada beberapa redaksi kata pada masing-masing kompetensi dasar dan materi, baik pada buku guru dan buku siswa maupun pada kurikulum.

\section{DAFTAR PUSTAKA}

Estiningtyas, N. N. (2015). Analisis Kesesuaian Buku Ajar Tema Indahnya Kebersamaan Kelas IV SD Dengan Kurikulum 2013. Trihaya: Jurnal Pendidikan KeSD-an, 186.

Fairuz, T. (2018). Pengembangan Bahan Ajar IPA Terpadu untuk Meningkatkan Keterampilan Berpikir Kritis dan Literasi Informasi Siswa SMP Pada Tema Interaksi Cahaya dengan Organisme. Tesis: UPI.

Fairuz, T. (2019). Analisis Kesesuaian Materi IPA Dalam Buku Ajar Kelas V SD/MI Dengan Kurikulum 2013. Jurnal Ilmiah Dalam Pendidikan Dasar, 79.

Fogarty, R. (1991). How to Integrate The Curricula. USA: Skylight Publishing.

Gusviani, R. (2016). Analisis Kemunculan Sikap Spiritual dan Sikap Sosial dalam Kegiatan Pembelajaran IPA Kelas IV SD yang Menggunakan KTSP dan Kurikulum 2013. EduHumaniora: Jurnal Pendidikan Dasar, 98.

Habudin dan Nova. (2017). Analisis Kesesuaian Isi Buku Kelas IV 
SD/MI Tema Cita-citaku Dengan Kurikulum 2013. Primary, 116.

Indahsari, B. A. (2018). Analisis Kesesuaian Buku Siswa Kelas IV Berbasis Kurikulum 2013 Tema "Pahlawanku"Subtema"Perjuangan Para Pahlawanku. Jurnal Pendidikan Sekolah Dasar dan Pendidikan dasar, 37.

Karli, Hilda, (2010), Penerapan Pembelajaran Tematik SD di Indonesia. EduHumaniora: Jurnal Pendidikan Dasar, 10

Majid, A. (2007). Perencanaan Pembelajaran. Bandung: Remaja Rosdakarya.

Mulyasa, E. (2013). Pengembangan Dan Implementasi Kurikulum 2013, Bandung : Remaja Rosdakarya.

Prastowo, Andi. (2014). Pengembangan Bahan Ajar Tematik. Jakarta: Kencana. 126.

Peraturan Menteri Pendidikan dan Kebudayaan Nomor 8 Tahun 2016 tentang Buku yang Digunakan Satuan Pendidikan.

Peraturan Menteri Pendidikan dan Kebudayaan Nomor 21 Tahun 2016 tentang Standar Isi Pendidikan Dasar dan Menengah. 